\title{
Zastupljenost vizualnih komunikacija u nastavnom procesu predmeta Likovna umjetnost na primjeru splitskih gimnazija
}

Gaj, Barbara; Brajnov Botić, Doroti; Violić, Duško

Source / Izvornik: Institucije povijesti umjetnosti : zbornik 4. kongresa hrvatskih povjesničara umjetnosti, 2019, 239 - 247

Conference paper / Rad u zborniku

Publication status / Verzija rada: Published version / Objavljena verzija rada (izdavačev PDF)

https://doi.org/10.31664/z4khpu.32

Permanent link / Trajna poveznica: https://urn.nsk.hr/urn:nbn:hr:254:890106

Rights / Prava: Attribution 4.0 International/Imenovanje 4.0 međunarodna

Download date / Datum preuzimanja: 2023-04-26

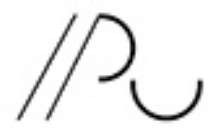

INSITIUT ZA POVIJESTUMJETNOSI
Repository / Repozitorij:

PODEST - Institute of Art History Repository

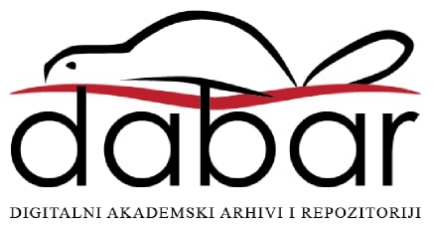




\section{Zastupljenost vizualnih \\ komunikacija u nastavnom
procesu predmeta Likovna
umjetnost na primjeru splitskih \\ komunikacija u nastavnom
procesu predmeta Likovna
umjetnost na primjeru splitskih \\ komunikacija u nastavnom
procesu predmeta Likovna
umjetnost na primjeru splitskih gimnazija}

\section{Barbara Gaj Doroti Brajnov Botić Duško Violić}

Barbara Gaj

Odsjek za likovnu kulturu i likovnu umjetnost

Umjetnička akademija u Splitu

Sveučilište u Splitu

bgaj@umas.hr

https://orcid.org/oooo-ooo2-5I47-3399

Doroti Brajnov Botić

Odsjek za likovnu kulturu i likovnu umjetnost Umjetnička akademija u Splitu

Sveučilište u Splitu

doroti@umas.hr

https://orcid.org/oooo-ooo3-3282-oI45

Duško Violić

Odsjek za likovnu kulturu i likovnu umjetnost

Umjetnička akademija u Splitu

Sveučilište u Splitu

dusko.violic@umas.hr

https://orcid.org/oooo-ooo2-6994-2886 posebice Radovan Ivančević i Vera Turković u povodu Prvoga hrvatskog kongresa InSEA-e održana I998. u Zagrebu, čiji je naslov bio Vizualna kultura i likovno obrazovanje u Hrvatskoj i svijetu. Vera Turković već je tada okarakterizirala naše školstvo kao nesuvremeno jer ne uvažava činjenicu da živimo u vremenu dominacije vizualne kulture i neusklađeno je sa značajkama suvremenog društva, naglašavajući kako slika danas ima primat u komunikološkom smislu i da svaki kvalitetan školski program stavlja „umjetničko obrazovanje u središte, osobito likovnu umjetnost”. ${ }^{1}$ U članku Likouni odgoj za treći milenij, Ivančević naglašava kako su internet i televizija najutjecajnija sredstva u procesu razvoja vizualne i likovne kulture današnjice, smatrajući da nas mediji drže u zabludi o informiranosti i nekoj vrsti iluzije. ${ }^{2}$ Manipulacija, neobjektivnost, zaglupljivanje i izvrnuta skala vrijednosti koje nam serviraju mediji imaju velik utjecaj na društvo. Ivančević navodi da je „uloga likovnog pedagoga i povjesničara umjetnosti razvijanje kritičkog mišljenja i istinska interpretacija slike svijeta koja nam se nudi". ${ }^{3}$ Naglašavajući društvenu odgovornost medija, Ivančević drži da su vizualne komunikacije potencijalno dobre za razvoj informiranja i mišljenja, za produbljivanje čovjekove spoznaje i unapređenje međuljudskih odnosa, ali da je za ostvarenje toga potreban velik napor zajednice. ${ }^{4}$

Unatoč tome što je dosad napisan niz radova i što su provedena brojna istraživanja o mjestu predmeta Likovna umjetnost $u$ srednjim školama i što postoje temeljni ishodi, strategije i smjernice predstavljeni u brojnim dokumentima, ${ }^{5}$ ta problematika nije dovoljno obrađena u znanstvenoj literaturi. Rad se bavi analizom zastupljenosti vizualnih komunikacija $u$ nastavi predmeta Likovna umjetnost u gimnazijama. Tako se još jednom želi skrenuti pozornost na degradaciju sama predmeta, zastarjelost važećeg plana i programa, koji nije mijenjan
I VERA TURKOVIĆ, Moć slike u obrazovanju, u: Vizualna kultura i likouno obrazovanje, (ur.) Radovan Ivančević, Vera Turković, Zagreb, Hrvatsko vijeće InSEA, 200I., $63-76,63$.

2 RADOVAN IVANČEviĆ, Likovni odgoj za treći milenij, u: Vizualna kultura i likovno obrazovanje, (ur.) Radovan Ivančević, Vera Turković, Zagreb, Hrvatsko vijeće InSEA, 200I., 77-94, 77, 79 .

3 RADOVAN IVANČEVIĆ (bilj. 2 ), 83,85 .

4 RADOVAN IVANČEVIĆ (bilj. 2), 92, 93 .

5 Nacionalni okvirni kurikulum za predškolski odgoj $i$ obrazovanje te opće obavezno i srednjoškolsko obrazovanje iz 20II.; Kome treba kreativnost? Strategija razuoja kreatiunosti u osnounoškolskom i srednjoškolskom obrazovanju, inicijalni dokument iz srpnja 20I4. (http://opa.hr/wp-content/uploads/sites/467/2015/o7/ strategija.pdf, posjećeno 28. veljače 2016.) i Nacionalni kurikulum nastaunoga predmeta Likouna kultura $i$ Likouna umjetnost-prijedlog, predstavljen u veljači 2or6. (http://www.kurikulum.hr/wp-content/uploads/2016/o3/Likovna-kultura-i-Likovna-umjetnost. pdf, posjećeno 29. veljače 20I6.) i dr. 
desetljećima i u konačnici na vrlo malu satnicu predmeta Likovna umjetnost u gimnazijama, neusporedivu sa satnicom zapadnoeuropskih zemalja. ${ }^{6}$

U vrijeme kad svakodnevno živimo okruženi vizualnim digitalnim medijima, u praksi je evidentna potreba za osuvremenjivanjem i interdisciplinarnošću nastave Likovne umjetnosti. Gradivo sama predmeta, kao i područje vizualnih komunikacija, trebalo bi se u procesu nastave više približiti stvarnom životu i komuniciranju putem slika, sve češće posredovanu digitalnim medijima.

Prema inicijalnom dokumentu Kome treba kreativnost? Strategija razuoja kreatiunosti u osnounoškolskom $i$ srednjoškolskom obrazovanju iz 20I4. godine, među ključnim ciljevima spomenuta je vizualna pismenost i vizualna komunikacija, kao i proučavanje uzročno-posljedičnih veza percepcije i kreativne reakcije, komunikacije i interpretacije. ${ }^{7}$ Prijedlog Nacionalnog kurikuluma nastaunoga predmeta Likouna kultura i Likouna umjetnost iz 20I6. godine daje smjernice prema kojima nastavne jedinice nisu strogo utvrdene ${ }^{8}$, a vizualne se komunikacije obrađuju unutar više tematskih sklopova, ponajviše unutar teme Umjetnost i moć u 4. razredu, u okviru koje je predviđena rasprava o prepletanju likovnih umjetnosti, popularne kulture, masovnih medija i vizualnih komunikacija, kao i o njihovu utjecaju na svakodnevni život. ${ }^{9}$

\section{Vizualne komunikacije i vizualna kultura}

Vizualne komunikacije definiraju se kao oblik i način prijenosa informacija suvremenim vizualnim medijima i kao takve uključuju masovne medije koji se temelje na vizualnim informacijama i utječu na promjenu ljudske percepcije te posredovanjem medijske komunikacije svijet postaje dostupniji. ${ }^{10}$ Suvremeni masovni mediji uključuju internet, kao i društvene mreže sveprisutne u svakodnevnoj vizualnoj komunikaciji. Specifičnost novih digitalnih medija jest neprestano redefiniranje i nadograđivanje, koje prati razvoj novih tehnologija. Tomu bi se svakako trebali prilagoditi obrazovni ishodi i ciljevi nastavnog programa jer se novi mediji u posljednjem desetljeću razvijaju gotovo nedohvatnom brzinom. Danas o vizualnim komunikacijama možemo govoriti u kontekstu vizualne kulture. Vizualna je kultura širok pojam koji se može definirati na više načina. Jedna od važnih odrednica vizualne kulture jest njezin aspekt obrazovne i odgojne djelatnosti njegovanja, čuvanja i razvijanja sposobnosti moći vizualnog opažanja te je odavno postala element masovne medijske i popularne kulture i ušla u sve pore javnog i privatnog života. ${ }^{11} \mathrm{Na}$ svakom se koraku susrećemo s vizualnim slikama i to u sve većem opsegu. Svakodnevno se, svjesno ili nesvjesno, sve više izražavamo slikama, a sve manje riječima, odnosno tekstom. Bez obzira sviđalo se to nekom ili ne, vizualna kultura ili „nekultura” jest ta koja je počela određivati granice komunikacije.

Preduvjeti za vizualnu kulturu jesu vizualna pismenos $\mathrm{t}^{12}$ i medijska pismenost. Autorica Zgrabljić Rotar smatra da je medijsko
6 Kome treba kreativnost? (bilj. 5), II.

7 Kome treba kreatiunost? (bilj. 5), 5 .

8 U prijedlogu Nacionalnog kurikuluma redoslijed tema nije nametnut, a aktivnosti i sadržaji ostvaruju se istraživanjem umjetničkog djela unutar povijesnoga, društvenog i umjetničkog konteksta te se likovnim problemima pristupa tematski, komparativno, sinkronijski ili dijakronijski. Nacionalni kurikulum (bilj. 5), 85 .

9 Odnosi se na domenu B 4.3, Nacionalni kurikulum (bilj. 5), 8I, 82 .

Io MIŠKO ŠUVAKOVIĆ, Pojmovnik suvremene umjetnosti, Zagreb, Horetzky, 20o5., 666.

II MIŠKO ŠUVAKOVIĆ (bilj. Io), 664 .

I2 Vera Turković navodi jednu od prvih definicija vizualne pismenosti koju je dao John Debes još ig68 godine (u djelu Some foundations of visual literacy): „Vizualna pismenost podrazumijeva skupinu vizualnih sposobnosti koje čovjek razvija gledanjem tako da istodobno razvija i povezuje i druga osjetilna iskustva. Razvoj tih kompetencija nužan je preduvjet za normalan proces učenja. [...] Kreativnom upotrebom tih kompetencija čovjek je osposobljen za komunikaciju s drugima. Odgovarajućim korištenjem ovih sposobnosti čovjek će moći razumjeti remek-djela vizualne komunikacije i u njima uživati." vERA TURKOVIĆ, Vizualna/likovna (ne)pismenost političkih stranaka u Hrvatskoj, u: Politička misao: časopis za politologiju, 46/I (2009.), II4-I34, II5. 
opismenjavanje u digitalnom dobu postalo ključno u suvremenom obrazovanju i naglašava kako je potrebno ukazati na nova tehnološka, društvena i humanistička znanja, a zatim osposobiti građane za analiziranje različitih medijskih sadržaja i njihovo vrednovanje. ${ }^{13}$ Medijska pismenost danas se najčešće odvija izvan obrazovnih ustanova jer se mlađa populacija u većoj mjeri koristi brojnim društvenim mrežama odnosno servisima. ${ }^{14}$ Siniša Kušić naglašava da roditelji, nastavnici i škole moraju biti ukorak s brzim razvojem informacijsko-komunikacijske tehnologije kako bi razumjeli načine utjecaja online društvenog umrežavanja na mlade te ih upozorili na njihove prednosti i nedostatke. ${ }^{15}$ Društvene mreže postaju sve više predmetom istraživanja psihologa, ekonomista, sociologa i ostalih stručnjaka kao specifičan fenomen današnjice. ${ }^{16}$

\section{Vizualne komunikacije u nastavi predmeta Likovna umjetnost}

Nastavna tema Vizualne komunikacije, prema planu i programu za gimnazije, za predmet Likovna umjetnost u gimnazijama predvidena je za 4. razred pod nastavnom jedinicom 2.I3. Vizualne komunikacije: TV, film, tisak u kojoj se stavlja naglasak na potrebu kritičkog odnosa prema vizualnoj stvarnosti i analizu medija kao što su televizija, film i tisak. ${ }^{17}$

Usporedbom odobrenih udžbenika za gimnazije predviđenih za nastavu predmeta Likovna umjetnost ${ }^{18}$ od ukupno četrnaest udžbenika samo dva udžbenika obrađuju Vizualne komunikacije. Jedan od njih je Likouni govor: Uvod u suijet likounih umjetnosti, udžbenik za I. razred gimnazije autora Radovana Ivančevića, ${ }^{19}$ a drugi Likouna umjetnost 4: udžbenik iz likoune umjetnosti za 4. razred srednjih škola s četverogodišnjim programom grupe autorica. ${ }^{20} \mathrm{U}$ poglavlju Vizualne komunikacije udžbenika Likouni govor autor se osvrće na medije kao što su fotografija, film, televizija, plakat, reklame i izlozi. ${ }^{21}$ Također, većinu teksta posvećuje televiziji kao najvažnijem i sveprisutnom mediju vizualnih komunikacija, kritički se osvrće na utjecaj medija i drži da je najozbiljniji problem našega doba zabluda o „objektivnoj” informaciji modernih tehnika vizualnih komunikacija. ${ }^{22}$ Udžbenik je pisan interdisciplinarnim i korelativnim pristupom, aktualnost medija koje autor spominje i dalje je relevantna, posebice u vremenu kada je nastao. Autori rada daju preporuku nastavnicima koji danas realiziraju nastavu prema navedenom udžbeniku da nastavnu jedinicu Vizualne komunikacije aktualiziraju i prilagode današnjem načinu života i komunikaciji putem suvremenih vizualnih medija i interneta. ${ }^{23}$

Udžbenik Likouna umjetnost 4 sadržava poglavlje Vizualne komunikacije, film, tisak, ${ }^{24} \mathrm{u}$ kojem se vizualna komunikacija definira kao „prenošenje poruka vizualnim putem, pomoću simbola, znakova, tekstova, slika, svako prenošenje misli grafičkim, fotografskim, filmskim, televizijskim ili nekim drugim putem". ${ }^{25}$ Naglasak je udžbenika na povijesnom razvoju vizualnih medija (pismu, grafičkom dizajnu, fotografiji, filmu i televiziji).
I3 NADA ZGRABLJIĆ ROTAR, Masovni mediji i digitalna kultura, u: Digitalno doba: masovni mediji i digitalna kultura, (ur.) Nada Zgrabljić Rotar, Zadar, Zagreb, Sveučilište u Zadru, Naklada medijska istraživanja, 2OII., 30, 3I.

I4 Najpoznatije društvene mreže su: Twitter, Instagram, Facebook, Flickr, MySpace, LinkedIn, Pinterest, Snapchat, MyLife, Ning LiveJournal, Tagged, Last. fm., itd.

I5 SINIŠA KUŠIĆ, Online društvene mreže i društveno umrežavanje kod učenika osnovne škole: navike Facebook generacije, u: Život $i$ škola, 24 (20Io.), I03-I25, I24.

I6 Društveno umrežavanje, www, u: Hrvatska enciklopedija, mrežno izdanje, (gl. ur.) Slaven Ravlić, Zagreb, Leksikografski zavod Miroslav Krleža, http://www. enciklopedija.hr/Natuknica.aspx?ID=664I3 (posjećeno 3. ožujka 2oi6.).

I7 U programskom sadržaju pod kritičkim odnosom predviđa se analiza vrhunskih dometa, najgorih promašaja i presjeka naše vizualne produkcije, zatim raščlamba vizualnog dizajna na TV programu, likovna nastojanja i vizualna kakvoća filmskog programa, kao i oprema knjiga, izgled tiska, plakati, reklame i izlozi. Nastauni program za gimnazije-Likouna umjetnost, Glasnik Ministarstva kulture i prosvjete, http:// dokumenti.ncvvo.hr/Nastavni_plan/gimnazije/obvezni/likovni.pdf (posjećeno 28. veljače 2oI6.).

I8 Katalog obveznih udžbenika i pripadnih dopunskih nastavnih sredstava za šk. god. 20I4./20I5., http:// public.mzos.hr/Default.aspx?art=I3I99 (posjećeno I5. siječnja 20I6.).

I9 RADOVAN IVANČEVIĆ, Likovni govor: Uvod u svijet likovnih umjetnosti, udžbenik za I. razred gimnazije, Zagreb, Profil International, I997.

20 NATALIJA STIPETIĆ ĆUS, ELEN ZUBEK, BLANKA PETRINEC FULIR, ZRINKA JURIĆ AVMEDOSKI, Likovna umjetnost 4, udžbenik iz likovne umjetnosti za 4. razred srednjih škola s četverogodišnjim programom, Zagreb, Alfa, 20I4.

2I RADOVAN IVANČEVIĆ (bilj. I9), 265-269.

22 RADOVAN IVANČEVIĆ (bilj. I9), 265 .

23 Udžbenik koji je analiziran u ovom tekstu objavljen je prije donošenja Udžbeničkog standarda i Zakona o udžbenicima za osnounu i srednju školu iz 20I3. godine.

24 NATALIJA STIPETIĆ ĆUS, ELEN ZUBEK, BLANKA PETRINEC FULIR, ZRINKA JURIĆ AVMEDOSKI (bilj. 20), I $32-\mathrm{I} 35$.

25 NATALIJA STIPETIĆ ĆUS, ELEN ZUBEK, BLANKA PETRINEC FULIR, ZRINKA JURIĆ AVMEDOSKI (bilj. 20), I32, I34. Pojašnjavajući dvosmjernu komunikaciju, autorice uz ,jezik gluhih i komunikaciju zastavicama na brodovima” navode i „SMs, kao i internetsko dopisivanje itd.", a internet se spominje još jednom u kontekstu grafičkog dizajna, prisutnog u ,gotovo svim područjima svakodnevnog života, u novinama, časopisima, udžbenicima, TV reklamama, video-spotovima, TV najavama, teletextu, plakatima, knjigama, na internetu". 
Općenito gledajući, poglavlje o vizualnim komunikacijama primjereno je obrađeno, s obzirom da je uvjetovano sažetošću koju nameće sama forma srednjoškolskog udžbenika te je sadržaj jasan i primjeren uzrastu završnog razreda gimnazije. Nedostatak jest nedovoljna uključenost suvremenih načina komuniciranja putem novih digitalnih medija ili primjerice, društvenih mreža, dok se internet kao medij vizualne komunikacije spominje sporadično.

Usporedbom udžbenika vidljivo je da Likouna umjetnost 4 grupe autorica daje jasan i sažet pregled povijesnoga razvoja pojedinih medija, dok Likouni govor naglašava utjecaj medija na društvo, posebno televizije, koja prema Ivančevićevu mišljenju ima negativne strane, ali i prednosti koje se mogu iskoristiti kao sredstvo edukacije u umjetničkom obrazovanju. Analizom sadržaja dvaju udžbenika može se zaključiti kako vizualna komunikacija putem digitalnih medija nije obrađena u tekstu. Nisu spomenute specifičnosti, prednosti i nedostaci takve vrste vizualnog komuniciranja, koje učenici srednjih škola učestalo koriste u svom svakodnevnom životu, kao ni uporaba suvremene tehnologije u umjetnosti, odnosno digitalizacija umjetnosti.

Nedostatak ostalih udžbenika s liste odobrenih udžbenika za gimnazije jest nezastupljenost vizualnih komunikacija u sadržaju i njihovim se izborom isključuje obrađivanje nastavne jedinice Vizualne komunikacije u nastavi.

Tri udžbenika koja nisu na popisu Kataloga odobrenih udžbenika za gimnazije za predmet Likovna umjetnost, a bave se problematikom vizualnih komunikacija u zasebnom poglavlju ili je ona djelomično zastupljena u sadržaju drugih poglavlja jesu: Likouna umjetnost ı: Osnouni elementi, oblici i urste likovnog govora autora Antuna Karamana, ${ }^{26}$ Neizvjesnost umjetnosti autorice Silve Kalčicic ${ }^{27}$ i Povijest umjetnosti 20. stoljeća Vladimira i Kristine Rismondo. ${ }^{28}$

\section{Neke odlike i principi novih medija}

Pod pojmom novih medija danas se podrazumijevaju digitalni mediji s posebnim naglaskom na internet, kojim se prenose digitalne slike i poruke. Prema Žarku Paiću, vrijeme u kojem živimo opisuju fenomeni informacijskog društva, poput „uvođenja digitalnih medija u svijet suvremene vizualne komunikacije: računala, grafički dizajn, web dizajn, televizija visoke definicije, interaktivno kućno kino, mobilna telefonija [...] te se digitalno doba odlikuje prijenosom informacija na daljinu, istodobnošću, ponovljivošću i mogućnostima pohrane informacija u nematerijalnome obliku digitalne slike." ${ }^{29}$ Vodeći svjetski teoretičar novih medija Lev Manovich u poznatom djelu Jezik novih medija pored ostalih odlika i principa navodi interaktivnost kao jedno od glavnih obilježja novih medija. Korisnik ima mogućnost odabira koji će element prikazati ili koji će slijed pratiti i na taj način postaje koautor djela. Računalna memorija novih medija omogućava podjednako brz i nasumičan pristup svakom elementu. ${ }^{30}$
26 ANTUN KARAMAN, Likovna umjetnost I: Osnovni elementi, oblici i vrste likovnog govora, udžbenik za I. razred gimnazije s dvogodišnjim programom likovne umjetnosti, Zagreb, Školska knjiga, 2005.

27 SILVA KALČIĆ, Neizvjesnost umjetnosti, udžbenik likovne umjetnosti za 4. razred gimnazije, Zagreb, Školska knjiga, 2005 .

28 VLADIMIR RISMONDO, KRISTINA RISMONDO, Povijest umjetnosti 2o. stoljeća, udžbenik likovne umjetnosti za 4. razred gimnazije i priručnik za nastavnike, Zagreb, Školska knjiga, 2012.

29 ŽARKO PAIĆ, Vizualne komunikacije-uvod, Zagreb, CVS-Centar za vizualne studije, 2008., I46-I47.

30 LEV MANOVIČ [LEV MANOVICH], Jezik novih medija, Beograd, Clio, 20I5., 9I, 97. 
Današnje mrežne stranice uglavnom su prilagođene svim komunikacijskim uređajima, a ne samo osobnom računalu kao što je prije bio slučaj. Isto je s programima koji su transformirani u aplikacije za mobitel i tablet i obrnuto. Aplikacije koje su osmišljene za pametni telefon sada se mogu instalirati na kućnom računalu, prijenosnom računalu i tabletu..$^{31}$ Današnja je komunikacija uvelike vizualna i odvija se u sferi virtualnih prostora, stoga je zadatak nastave vizualnih komunikacija razviti kritički stav i mišljenje kod učenika kako bi razlikovanje umjetnički vrijednih sadržaja od komercijalnih poruka bilo što jasnije.

\section{Prikupljanje podataka, rasprava o rezultatima i smjernice}

Cilj je istraživanja bio uvid u učestalost, odgojno-obrazovnu vrijednost i načine korištenja vizualnih komunikacija unutar nastave Likovne umjetnosti u splitskim gimnazijama i njihovu zastupljenost u svakodnevnom životu učeničke populacije. Istraživanje je provedeno u svrhu utvrđivanja navika, stavova i mišljenja učenika/ica i provjere znanja osnovnih pojmova u vizualnim komunikacijama i vizualnoj percepciji. Pretpostavke prije provedena istraživanja jesu nedovoljna zastupljenost suvremenih vizualnih komunikacija u planu i programu, a time i u sadržaju odobrenih udžbenika za gimnazije, te izražena komunikacija putem društvenih mreža uz učestalu uporabu vizualnih poruka.

Kao metoda ispitivanja odabrano je pismeno anketiranje uz pomoć anonimnog upitnika s pitanjima zatvorenoga tipa. Ispitivanje je provedeno kao neposredno grupno anketiranje $u 4$. razredima splitskih gimnazija. Razlog odabira isključivo učenika/ica 4. razreda gimnazije jest to što se prema nastavnom planu i programu nastavna jedinica Vizualne komunikacije za predmet Likovna umjetnost može obrađivati u prvom ili četvrtom razredu. ${ }^{32}$ Anketiranje su proveli autori u splitskim gimnazijama u travnju i svibnju 20I6. godine, uz odobrenje ravnatelja i suradnju nastavnika iz predmeta Likovna umjetnost. Ispitanici/ice su bili upoznati sa svrhom istraživanja prije anketiranja.

Prvi dio upitnika odnosio se na opća pitanja o učenju i izvođenju nastavnog predmeta na koja su bili ponuđeni odgovori dihotomnog tipa DA-NE. Drugi dio upitnika odnosio se na mišljenje i navike, gdje su se odgovori izražavali s pomoću procjene intenziteta na numeričkoj skali od I do 5 te kao ponuđeni odgovori višestrukog izbora pod $a, b$ i $c$. Treći dio upitnika odnosio se na pitanja o pojmovima nastavne jedinice Vizualne komunikacije.

Uzorak istraživanja sačinjavala je učenička populacija završnih razreda splitskih gimnazija, a ukupno je ispitano 589 osoba, od čega 358 pripadnica ženskog roda i 23I pripadnik muškog roda. Rezultati istraživanja obrađeni su i prikazani grafički (s pomoću dijagrama), numerički (brojevima, postocima) i deskriptivno.

U prvom dijelu anketnog istraživanja provedena među učenicima/icama četvrtih razreda splitskih gimnazija zastupljena su pitanja o vizualnom učenju, korištenju elektroničkih medija
3I Neke su od poznatih aplikacija prilagođenih za više komunikacijskih uređaja Skype, Viber ili WhatsApp, putem kojih je moguće razmjenjivati poruke, pozive, fotografije, slike, kao i audio- i videozapise. Na društvenim mrežama postoje razne aplikacije koje je također moguće instalirati na mobilnim uređajima i računalima, a služe za komunikaciju ili primjerice za određivanje lokacije na kojoj se trenutno nalazimo.

$3^{2}$ Stoga je bilo relevantno ispitati učenike kojima je to gradivo tumačeno. 
za razmjenu nastavnih materijala, kao i o omjeru uključivanja videoisječaka, animacija i dokumentarnih filmova u nastavu predmeta Likovna umjetnost. Prema dobivenim podacima možemo zaključiti da veliki postotak učenika/ica uči vizualno $(85,90 \%)$ i sluša nastavu uz korištenje prezentacija (99,I5\%), dok je tek nešto više od pola ispitanika/ica (50,93\%) izjavilo da su u nastavnom procesu uključeni videoisječci, animacije i dokumentarni filmovi. Veliki postotak učenika/ica $(75,6 \mathrm{I} \%)$ odgovorio je da ne razmjenjuje materijale s predmetnim nastavnikom/icom elektroničkim putem (sl. I).

U drugom dijelu ankete pitanja se odnose na nedovoljnu zastupljenost prenošenja vizualnih poruka putem novih digitalnih medija u nastavi i udžbenicima za predmet Likovna umjetnost i na navike mladih u komuniciranju putem interneta, odnosno društvenih mreža ili servisa. Rezultati pokazuju da je dio ispitanika/ica neodlučan (45,67\%), a dio (30,73\%) smatra da je u udžbeniku nedovoljno obrađeno prenošenje vizualnih poruka novim digitalnim medijima-internetom, mobitelom i sl., dok ostatak $(23,26 \%)$ smatra suprotno. Nadalje,

\section{Slika I}

Razmjenjujete li s predmetnim nastavnikom-icom materijale za nastavu elektronskim putem?

$\mathbf{7 5 , 6 1 \%} \mathrm{Ne}$

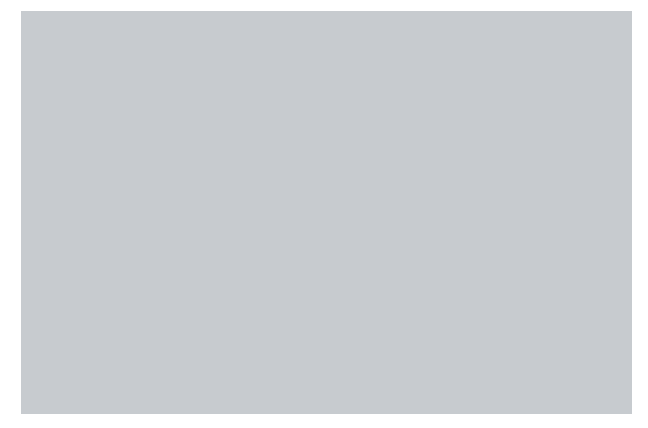

$\mathbf{2 4}, \mathbf{0} 5 \% \quad \mathrm{Da}$

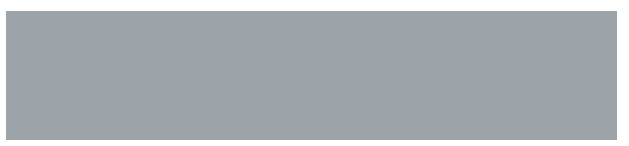

$\mathbf{0 , 3 4} \%$ Bez odgovora

\section{Slika 2}

U svakodnevnoj komunikaciji više koristite vizualne poruke- fotografije, ilustracije, naljepnice, emotikone i tekst nego što razgovarate putem mobitela?

$\mathbf{3 6 , 1 7 \%} \quad$ Nimalo se ne slažem

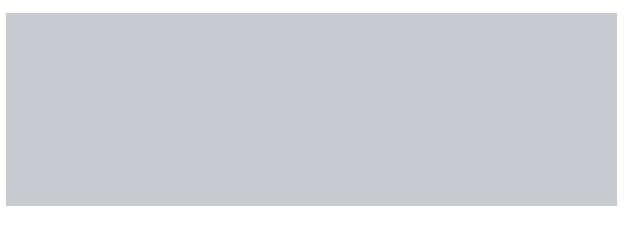

$\mathbf{3 4 , 6 3 \%} \quad$ Ne slažem se

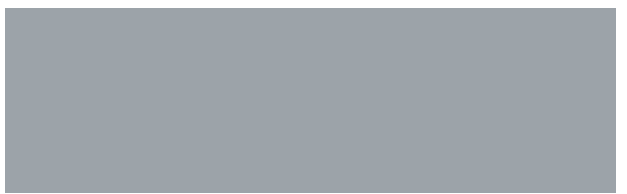

$\mathbf{I 5}, \mathbf{6 2} \% \quad$ Niti se slažem, niti se ne slažem

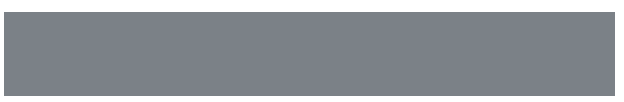

$\mathbf{9 , 8 5 \%} \quad$ Slažem se

$\mathbf{3 , 3 9 \%} \quad$ U potpunosti se slažem

$\mathbf{0 , 3 4 \%}$ Bez odgovora 
više od dvije trećine učenika/ica (70,80\%) slaže se ili se u potpunosti slaže da u svakodnevnom komuniciranju pretežito koriste vizualne poruke (sl. 2).

Rezultati pitanja o tome imaju li učenici/ice profile na društvenim mrežama i koliko vremena provode na internetu pokazuju da većina učenika/ica imaju barem jedan profil na nekoj od društvenih mreža (97,45\%), odnosno više od pola ukupnog broja ispitanika/ica ima po jedan profil (54,5\%), dok ostali učenici/ice imaju po dva ili više profila (42,95\%). Postotak onih koji nemaju profila na društvenim mrežama vrlo je malen $(2,04 \%)$, što pokazuje da većina učenika/ica tog uzrasta ima profil na nekoj od društvenih mreža (sl. 3). Također, rezultati pokazuju i da većina učenika/ica $(86,75 \%)$ provodi više od sat vremena dnevno u komunikaciji na internetu, a od ukupnog broja ispitanika/ica (58,40\%) provodi čak više od dva sata dnevno (sl. 4). Iz tih podataka zaključujemo da danas većina mladih ljudi svakodnevno koristi aplikacije za dopisivanje, e-poštu i društvene mreže te je suvremena komunikacija među učeničkom populacijom danas naprosto nezamisliva bez tih servisa.

\section{Slika 3}

Imate li profil na nekoj društvenoj mreži

(Facebook, Twitter, Instagram i sl.)?

$\mathbf{5 4 , 5 0} \%$ Imam profil

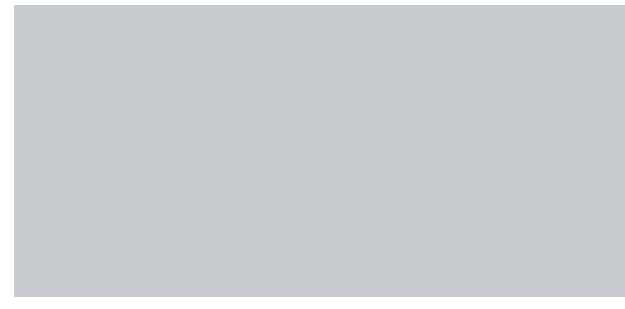

$\mathbf{4 2 , 9 5 \%}$ Imam dva ili više profila

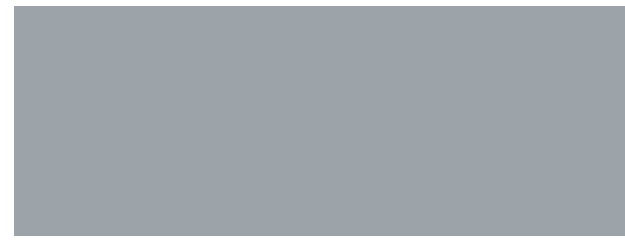

$\mathbf{2 , 0 4} \%$ Nemam profil

$\mathbf{0 , 5} \mathbf{1} \%$ Bez odgovora
Slika 4

Koliko vremena dnevno komunicirate putem elektronskih medija: aplikacija za dopisivanje (Viber, Whatsapp, Snapchat i sl.), e-pošte i društvenih mreža?

$\mathbf{5 8 , 4 0 \%} \quad 2$ h i više

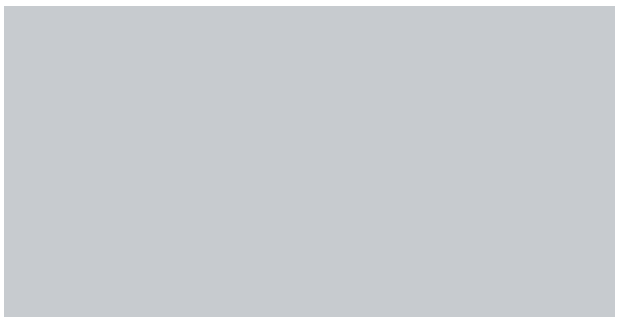

$\mathbf{2 8 , 3 5 \%}$ Od Ih do $2 \mathrm{~h}$

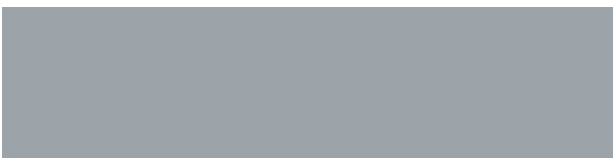

$\mathbf{I 2 , 2 2} \%$ Manje od Ih

$\mathbf{I}, \mathbf{0} 3 \%$ Bez odgovora 
Kada je riječ o trećoj skupini pitanja, većina učenika pokazala je poznavanje osnovnih pojmova iz nastavne jedinice Vizualne komunikacije, odnosno gradivo iz udžbenika koji se koriste u nastavi predmeta Likovna umjetnost. Točnu definiciju vizualnih komunikacija odabralo je $79,29 \%$ učenika/ica, dok ih gotovo petina $(\mathrm{I} 7,49 \%)$ smatra da je to verbalna komunikacija (posredovana masovnim medijima). Čak 97,II\% prepoznalo je vizualne medije, a pojam logotipa bio je poznat većini (9I,68\%), kao i kronološka starost pisma kao začetak medija (92,70\%). Mišljenja su bila podijeljena po pitanju definicije stripa, filma i animacije i bila su dosta različita pa je tek nešto više od petine ispitanika/ica (2I,40\%) odabralo točan odgovor. Kod prepoznavanja znaka, samo ih je I3,75\% odgovorilo točno. Na pitanje o vizualnom opažanju (optičkim iluzijama), samo 4I,I6\% učenika/ica pokazalo da ima razvijenu vizualnu percepciju.

Ispitivanje je provedeno u pet državnih gimnazija u Splitu i jednoj privatnoj. Ispitanici pripadaju manjem zemljopisnom području (grad Split) među kojima nema velikih kulturoloških i socioloških razlika. Rezultati odražavaju trenutnu situaciju unutar institucija gimnazijskog obrazovanja u Splitu te pokazuju navike, stavove i mišljenja učenika 4. razreda splitskih gimnazija. Analizom dobivenih rezultata potvrđene su neke od postavljenih pretpostavki prije provedena istraživanja.

Uz one opće smjernice na kojima se temelji suvremena nastava (otvorenost nastave: humanistički pristup, akcijska nastava, iskustvena nastava, okretanje prema učenicima, traženje vlastitih putova učenja, učenje kao samoaktivni proces, uporaba dokumentarnih filmova, animacija i videoisječaka...), koje mogu vrijediti za razna područja, na ovome mjestu navodimo nekoliko konkretnih smjernica kojima bi se moglo konstruirati znanje iz područja vizualnih komunikacija u sklopu nastave. Jedan od prijedloga jest izrada bloga ili grupe na nekoj od društvenih mreža na kojima bi predmetni nastavnici razmjenjivali materijale s učenicima. Zatim poticanje učenika na korištenje službenih mobilnih aplikacija svjetskih muzeja i umjetničkih galerija u svrhu upoznavanja sa stilskim razdobljima i umjetničkim djelima.

\section{Zaključak}

Na temelju rezultata dobivenih istraživanjem može se zaključiti da vizualne komunikacije nisu dovoljno zastupljene $u$ planu i programu, a ni u odobrenim udžbenicima. Udžbenici ne obrađuju dovoljno obilježja novih medija kao ni vizualno komuniciranje u suvremenom medijskom okruženju, a ne spominje se dovoljno ni digitalizacija suvremene umjetnosti.

U sadržaj predmeta svakako bi trebalo uključiti internet i ostale digitalne medije kao posrednike vizualnih komunikacija. Nastavni proces trebao bi više senzibilizirati učenike za medijsku pismenost i ulogu vizualne komunikacije odnosno vizualnog u javnom komunikacijskom prostoru i različitih vidova sadržaja vizualne poruke u virtualnim sferama svakodnevne komunikacije. Sadržaj i uloga vizualnih komunikacija 
u nastavi trebali bi naglašavati razvoj kritičkog mišljenja i senzibiliziranje učenika za razlikovanje umjetničkih djela od reklamnih poruka, kao i kvalitetnih sadržaja od nekvalitetnih i likovno bezvrijednih u današnjoj hiperprodukciji i razmjeni slika, fotografija i vizualnih poruka.

Neovisno o tome hoće li novi kurikulum biti implementiran u srednjoškolsko obrazovanje, Nastavni plan i program za predmet Likovna umjetnost nužno iziskuje osuvremenjivanje, kao i dopunu sadržaja udžbenika. Sadašnji udžbenici trebat će se uskladiti s novim ciljevima i ishodima učenja, a u nastavnom procesu bit će potrebno primijeniti nove metode i pristupe uz još više izvanučioničke nastave. Reforma školstva i implementacija novoga kurikuluma zahtijeva dodatnu edukaciju nastavnika, a ne samo prilagođavanje udžbenika i nastavnog materijala. To se odnosi i na vizualne komunikacije, koje ne moraju nužno biti samo zasebna nastavna jedinica, već se mogu obrađivati u sklopu većih tematskih cjelina, uz neizostavan interdisciplinarni pristup. Promjene se ne bi trebale odnositi samo na dopunu i izmjenu sadržaja predmeta i nastavnih cjelina nego i na sam nastavni proces, način poučavanja i izvođenja nastave, uz prilagodbu današnjem načinu života i komuniciranja.

Provedeno istraživanje ostavlja prostor za dalje propitivanje i utvrđivanje smjernica za poboljšanje nastave vizualnih komunikacija, kao i nastavnog procesa predmeta Likovna umjetnost. Budućnost nam možda donosi i udžbenike u elektroničkoj formi koje će učenici moći koristiti na tabletu ili prijenosnom računalu, kao i razvoj interaktivnih aplikacija razvijenih upravo za nastavu Likovne umjetnosti za digitalne komunikacijske uređaje. Logična je pretpostavka da su moguće i promjene $u$ nazivu samoga predmeta $u$, primjerice, Vizualna umjetnost (i kultura) čije bi gradivo obuhvaćalo mnogo šire $i$ više interdisciplinarno područje, možda u nekom smislu prilagođeno današnjem načinu života i komunikacije, no to ostavljamo na prosudbu struci i nekim budućim mijenama u školskom sustavu.

\section{() (1)}

Zastupljenost vizualnih komunikacija u nastavnom procesu predmeta Likovna umjetnost na primjeru splitskih gimnazija / Barbara Gaj/ Doroti Brajnov Botić / Duško Violić / CC BY / 4.o

DOI: https://doi.org/ıo.3I664/z4khpu.32 